\title{
Genetic Diversity and Structure of Ruzigrass Germplasm Collected in Africa and Brazil
}

\author{
Marco Pessoa-Filho,^ Ana Luisa S. Azevedo, Fausto S. Sobrinho, Ediene G. Gouvea, \\ Alexandre M. Martins, and Márcio E. Ferreira
}

\begin{abstract}
Ruzigrass [Urochloa ruziziensis (R. Germain \& Evrard) Crins, syn. Brachiaria ruziziensis Germain \& Evrard] is a tropical forage native to Africa, first introduced in Brazil in the 1960s. Ruzigrass is diploid, presents sexual reproduction, and is a model species for the generation of genomic resources in the Brachiaria genus. Brachiaria species are the most important livestock forage in the tropics, covering more than 70 million ha in Brazil alone. We have used multiplex panels of microsatellite markers to characterize the genetic diversity of ruzigrass germplasm collected in Africa, and of a local population collected in Brazil, to obtain information for its conservation and use in breeding programs. Fifteen SSR markers were used to Genotype 114 ruzigrass samples. Summary statistics, as well as estimates of $F_{S T}$ and partitioning of genetic diversity were obtained. Clustering and genetic structure analyses were performed. Results showed high values of heterozygosity in the African and Brazilian populations. Although African and Brazilian samples formed distinct groups in clustering analyses, and Bayesian analysis of genetic structure distributed samples into three clusters, estimates of pairwise $F_{S T}$ values showed no differentiation between African and Brazilian groups of samples. Results indicated that the introduction of ruzigrass in Brazil did not cause a major decrease in genetic diversity. Brazilian local populations might harbor favorable alleles that will be useful for ongoing and future breeding programs. They offer great opportunities for ruzigrass germplasm collection and conservation of genetic diversity, before attempts to access germplasm in its center of diversity are undertaken.
\end{abstract}

M. Pessoa-Filho, Embrapa Cerrados, P.O. Box 08223, Brasília, DF, Brazil 73310-970; A.L.S. Azevedo, F.S. Sobrinho, Embrapa Dairy Cattle, Rua Eugênio do Nascimento, 610, Juiz de Fora, MG, Brazil 36038-330; E.G. Gouvea, A.M. Martins, M.E. Ferreira, Embrapa Genetic Resources and Biotechnology, P.O. Box 02372, Brasília, DF, Brazil 70770-917; A.M Martins, Dep. Biologia Celular, Univ. de Brasília (UnB) Campus Universitário Darcy Ribeiro, Asa Norte, Brasília, DF, Brazil 70910-900. Sponsored by Embrapa Macroprograma 2 (02.12.02.002.00.00). Received 13 Feb. 2015. Accepted 31 July 2015. ^Corresponding author (marco.pessoa@embrapa.br).

Abbreviations: Embrapa, Empresa Brasileira de Pesquisa Agropecuária; $H_{\mathrm{E}}$, expected heterozygosity; $H_{\mathrm{O}}$, observed heterozygosity; PCA, principal component analysis; PIC, polymorphism information content; SSR, simple sequence repeat.

$\mathrm{R}$ UZIGRASS is a tropical forage native to Africa, found in regions such as the Ruzizi Valley, in the Democratic Republic of the Congo and Burundi. Germplasm of this species was originally obtained from Rwanda, multiplied in Kenya in the early 1960s, and then spread to continental Africa and Madagascar. From Madagascar, it was sent to Australia (Keller-Grein et al., 1996). Reports mention its first introduction in Brazil also in the 1960s, probably after its release in Australia as cultivar Kennedy, by the Queensland Herbage Plant Liaison Committee, in 1966 (Keller-Grein et al., 1996).

Early reports of germplasm collections of ruzigrass date back to the 1950s, led by the National Agricultural Research Station in Kitale, Kenya (Keller-Grein et al., 1996). A second initiative took place in eastern Africa, in 1984 and 1985. It was supported by the International Board for Plant Genetic Resources (IBPGR, now Bioversity International), and the International Livestock Centre for Africa (ILCA, which took part on the foundation of

Published in Crop Sci. 55:2736-2745 (2015).

doi: 10.2135/cropsci2015.02.0096

Freely available online through the author-supported open-access option.

(C) Crop Science Society of America | 5585 Guilford Rd., Madison, WI 53711 USA

All rights reserved. 
the International Livestock Research Institute, ILRI). These accessions were deposited in the germplasm collection of the International Center for Tropical Agriculture (CIAT) and, in 1987, were brought to Brazil for agronomic evaluations performed by the Brazilian Agricultural Research Corporation (Empresa Brasileira de Pesquisa Agropecuária, Embrapa), for their use as forage in the new agricultural frontier of the Brazilian Cerrados.

Currently, a small number of ruzigrass accessions are kept in a few gene banks, either as seed or as plants in the field. Embrapa keeps only 13 accessions in long-term preservation conditions at its Base Collection, and a few more accessions are kept in vivo in active germplasm collections. At the time of writing, a search on Genesys, a database designed to provide access to information about worldwide gene bank accessions (http://www.genesys-pgr.org, last accessed on 28 Jan. 2015), lists only 80 ruzigrass entries in three gene banks. The ILRI, in Ethiopia, holds 30 accessions; CIAT, in Colombia, keeps 42 accessions; and the USDA-ARS Plant Genetic Resources Conservation Unit at the University of Georgia, in the United States, harbors five ruzigrass accessions. Since some of these accessions are certainly duplicates, and most of them were collected in the expedition that took place in the mid-1980s, mentioned above, the number of unique ruzigrass accessions kept in gene banks will probably not reach more than 50 samples.

Although it is known for its high nutritional quality and palatability, ruzigrass use has been historically hindered due to its high susceptibility to spittlebugs (Mahanarva spectabilis and Deois schach), and to its lower yields when compared to cultivars from other Brachiaria species, such as B. brizantha cultivar Marandu and B. decumbens cultivar Basilisk (Keller-Grein et al., 1996). Recent growth in the use of integrated crop-livestock systems in the tropics, and in Brazil in particular, has raised interest in ruzigrass. An expected area of 15 million ha of degraded pastures should be recovered in the country for use in integrated systems in the next few years (Kichel et al., 2014). Consequently, the opportunity for ruzigrass breeding, cultivar development and seed production has also increased. Ruzigrass use in integrated crop-livestock systems has been successful due to its small tussock architecture, its low herbicide need for desiccation, as well as its good adaptation to overseeding (Azevedo et al., 2011).

In contrast to apomictic species in the genus that are used as tropical forages (namely B. brizantha, B. decumbens, and $B$. humidicola), ruzigrass presents sexual reproduction. This allows and calls for the use of breeding methods to obtain diverse cultivars improved for traits of interest. A breeding program for ruzigrass using recurrent selection has been recently initiated at Embrapa Dairy Cattle (Souza Sobrinho et al., 2009b), based on crossings among accessions collected in pastures established decades ago, in southeastern Brazil. To our knowledge, this is the only breeding program for a diploid species of Brachiaria being currently conducted in Brazil and, perhaps, in other parts of the world. One of its first goals is to obtain an improved population for the species, while maintaining genetic diversity for different important forage traits. Intrapopulation recurrent selection has been applied to increase the frequency of favorable alleles for traits such as forage yield, nutritional quality, spittlebug resistance, aluminum toxicity tolerance, and shading tolerance (Souza Sobrinho et al., 2009a). Results from the first selection cycle showed that there is genetic diversity for several economically important traits (Souza Sobrinho et al., 2009a). Heritability, genetic gains, and correlations among traits have been evaluated, indicating great potential for genetic improvement of this species (Borges et al., 2011).

Microsatellites have long been the standard class of molecular markers for genetic characterization of germplasm accessions. In forage grasses, for instance, microsatellites have been used for the characterization of genetic diversity in perennial ryegrass (Lolium perenne L.) (Kubik et al., 2001; Brazauskas et al., 2011), Paspalum (Cidade et al., 2013), napier grass (Pennisetum purpureum Schum.) (Azevedo et al., 2012), guineagrass (Panicum maximum Jacq.) (de Sousa et al., 2011), tall fescue (Festuca arundinacea Schreb.), and meadow fescue (F. pratensis Huds.) (Hand et al., 2012), bermudagrass (Cynodon spp.) (Jewell et al., 2012), and Kentucky bluegrass (Poa pratensis L.) (Honig et al., 2012; Bushman et al., 2013). Among the four commercially important Brachiaria species, microsatellites have been developed for B. brizantha and B. humidicola (Jungmann et al., 2009a, 2009b; Vigna et al., 2011a). Some of these markers have been used to characterize germplasm collections of these species kept in Brazil (Jungmann et al., 2010; Vigna et al., 2011b). Recently, we developed a first set of 500 microsatellite markers for ruzigrass using Illumina sequencing data and a draft de novo genome assembly (Silva et al., 2013). We tested 269 of these markers, 198 of which were polymorphic for 11 ruzigrass samples (Silva et al., 2013). Based on this initial test, multiplex panels were set up for microsatellite markers with the highest values of polymorphism information content (PIC) (Silva et al., 2013).

Use of molecular markers in assessments of genetic diversity of ruzigrass germplasm and breeding populations has been so far limited to dominant markers such as RAPDs (Ambiel et al., 2008, 2010) and ISSRs (Azevedo et al., 2011). The present study uses microsatellite markers for the characterization of germplasm of this species. Our objectives were to evaluate the genetic diversity and structure of germplasm accessions originally collected in Africa, and of samples of a local population of its commercially available open-pollinated variety, collected in a ruzigrass production site in Brazil. 


\section{MATERIALS AND METHODS Plant Material and DNA Extraction \\ African Germplasm}

Thirteen accessions of $B$. ruziziensis were kindly provided by Dr. Juliano Gomes Pádua (Embrapa Genetic Resources and Biotechnology, Brasilia, DF, Brazil). These accessions were originally collected in Africa, and maintained as frozen seed for the last $30 \mathrm{yr}$ in the long-term Base Collection kept at Embrapa Genetic Resources and Biotechnology. Their identification codes and countries of origin are listed on Table 1. Five plants of each accession were used in this study, totaling 65 samples.

\section{Brazilian Local Population}

Young leaves of 51 plants selected at random across a ruzigrass field in the municipality of Chapada Gaucha, Minas Gerais, were collected for DNA analysis. They represent a sample of the ruzigrass variety commercially available in Brazil, locally known as cultivar Kennedy, an open-pollinated variety which is extensively planted in the country. It is believed that the current open-pollinated variety traces back to the cultivar released in Australia as cultivar Kennedy (Keller-Grein et al., 1996).

Seeds were immersed in $\mathrm{H}_{2} \mathrm{SO}_{4}$ for 15 min to overcome seed dormancy, and then rinsed in distilled water for $5 \mathrm{~min}$. Treated seeds were sown in trays containing potting soil, and kept in the greenhouse. DNA was extracted from young leaves of germinated plantlets or, otherwise, from young leaves of plants collected in the field, using a standard CTAB protocol (Doyle and Doyle, 1987) with modifications, as described in Ferreira and Grattapaglia (1998). DNA concentrations were measured on a Nanodrop 2000 spectrophotometer (Thermo Scientific, Waltham, MA), and samples were diluted on TE buffer $\mathrm{pH} 8.0$ to a concentration of $2 \mathrm{ng} / \mu \mathrm{L}$.

\section{Genotyping with Multiplex Panels of SSR Markers}

Fifteen SSR markers described in Silva et al. (2013) were used in this study. Polymerase chain reaction (PCR) mixtures contained $15 \mathrm{ng}$ of genomic DNA, $0.7 \mathrm{U}$ of Taq DNA polymerase, $0.2 \mathrm{mM}$ of each dNTP, $0.2 \mu \mathrm{M}$ of each primer, $1.5 \mathrm{mM}$ of $\mathrm{MgCl}_{2}, 20 \mathrm{mM}$ Tris- $\mathrm{HCl} \mathrm{pH} 8.3$ and $50 \mathrm{mM} \mathrm{KCl}$, in a final volume of $8 \mu \mathrm{L}$. Cycling parameters consisted of an initial step at $94^{\circ} \mathrm{C}$ for 5 , 30 cycles of $94^{\circ} \mathrm{C}$ for $30^{\prime},, 52^{\circ} \mathrm{C}$ for $90^{\prime \prime}, 72^{\circ} \mathrm{C}$ for $60^{\prime}$, and a final extension step at $60^{\circ} \mathrm{C}$ for $60^{\prime}$. Forward primers were 5'-end labeled with fluorescent dyes (6-FAM, HEX, or NED). The amplification reactions were performed with a GeneAmp PCR-System 9700 (Applied Biosystems, Foster City, CA). The PCR products were precipitated, suspended in $10 \mu \mathrm{L}$ of Milli-Q water, and kept frozen until use. Products were denatured at $94^{\circ} \mathrm{C}$ for $5 \mathrm{~min}$. Denatured products were injected in a MegaBACE 1000 (GE Healthcare Life Sciences, Pittsburgh, PA) automated sequencer. Allele size calling and genotyping were carried with Fragment Profiler v1.2. Automated allelic binning was performed with AlleloBin [http://www.icrisat.org/bt-software-d-allelobin.htm, last accessed on 28 Jan. 2015], based on an algorithm described by Idury and Cardon (1997).
Table 1. List of analyzed ruzigrass accessions, their corresponding accession codes, countries of origin, collector's information, and year of collection.

\begin{tabular}{|c|c|c|c|c|}
\hline Sample & $\begin{array}{c}\text { Accession } \\
\text { no. }\end{array}$ & $\begin{array}{l}\text { Country } \\
\text { of origin }\end{array}$ & $\begin{array}{l}\text { Collector's } \\
\text { information }\end{array}$ & $\begin{array}{l}\text { Year of } \\
\text { collection }\end{array}$ \\
\hline AG-01 & $\begin{array}{l}\text { BRA-005541 } \\
\text { (CIAT 16551) }\end{array}$ & Kenya & $\begin{array}{c}\text { Gerhard Keller- } \\
\text { Grein, Salomon } \\
\text { Mengitsu }\end{array}$ & 1984 \\
\hline AG-02 & $\begin{array}{l}\text { BRA-005550 } \\
\text { (CIAT 26162) }\end{array}$ & Burundi & $\begin{array}{c}\text { Gerhard Keller- } \\
\text { Grein }\end{array}$ & 1985 \\
\hline AG-03 & $\begin{array}{l}\text { BRA-005568 } \\
\text { (CIAT 26163) }\end{array}$ & Burundi & $\begin{array}{c}\text { Gerhard Keller- } \\
\text { Grein }\end{array}$ & 1985 \\
\hline AG-04 & $\begin{array}{l}\text { BRA-005576 } \\
\text { (CIAT 26167) }\end{array}$ & Burundi & $\begin{array}{c}\text { Gerhard Keller- } \\
\text { Grein }\end{array}$ & 1985 \\
\hline AG-05 & $\begin{array}{l}\text { BRA-005584 } \\
\text { (CIAT 26168) }\end{array}$ & Burundi & $\begin{array}{c}\text { Gerhard Keller- } \\
\text { Grein }\end{array}$ & 1985 \\
\hline AG-06 & $\begin{array}{r}\text { BRA-005592 } \\
\text { (CIAT 26170) }\end{array}$ & Burundi & $\begin{array}{c}\text { Gerhard Keller- } \\
\text { Grein }\end{array}$ & 1985 \\
\hline AG-07 & $\begin{array}{c}\text { BRA-005606 } \\
\text { (CIAT 26171) }\end{array}$ & Burundi & $\begin{array}{c}\text { Gerhard Keller- } \\
\text { Grein }\end{array}$ & 1985 \\
\hline AG-08 & $\begin{array}{r}\text { BRA-005614 } \\
\text { (CIAT 26174) }\end{array}$ & Burundi & $\begin{array}{c}\text { Gerhard Keller- } \\
\text { Grein }\end{array}$ & 1985 \\
\hline AG-09 & $\begin{array}{r}\text { BRA-005622 } \\
\text { (CIAT 26175) }\end{array}$ & Burundi & $\begin{array}{c}\text { Gerhard Keller- } \\
\text { Grein }\end{array}$ & 1985 \\
\hline AG-10 & $\begin{array}{l}\text { BRA-005631 } \\
\text { (CIAT 26177) }\end{array}$ & Burundi & $\begin{array}{c}\text { Gerhard Keller- } \\
\text { Grein }\end{array}$ & 1985 \\
\hline AG-11 & $\begin{array}{l}\text { BRA-005649 } \\
\text { (CIAT 26178) }\end{array}$ & Burundi & $\begin{array}{c}\text { Gerhard Keller- } \\
\text { Grein }\end{array}$ & 1985 \\
\hline AG-12 & $\begin{array}{l}\text { BRA-005665 } \\
\text { (CIAT 26347) }\end{array}$ & Rwanda & $\begin{array}{c}\text { Gerhard Keller- } \\
\text { Grein }\end{array}$ & 1985 \\
\hline AG-13 & $\begin{array}{l}\text { BRA-005673 } \\
\text { (CIAT 26350) }\end{array}$ & Rwanda & $\begin{array}{c}\text { Gerhard Keller- } \\
\text { Grein }\end{array}$ & 1985 \\
\hline
\end{tabular}

\section{Statistical Analyses}

Individuals and loci with more than 20\% missing data were excluded from the database to avoid potential distortions in the statistical analysis. PowerMarker v. 3.25 (Liu and Muse, 2005) was used to generate a table of summary statistics for all loci, as well as estimates of the total number of alleles (A), observed heterozygosity $\left(H_{\mathrm{O}}\right)$, expected heterozygosity $\left(H_{\mathrm{E}}\right)$, and PIC. The expected gene diversity was calculated based on the unbiased estimator formed by the ratio between the expected heterozygosity $\left(1-\Sigma_{\mathrm{i}} \mathrm{p}_{\mathrm{i}}{ }^{2}\right)$ and the factor $(2 n) /(2 n-1)$; being $\mathrm{p}_{\mathrm{i}}$ the frequency of the $i$ th allele for each locus and $n$ the number of analyzed samples (Nei, 1987); the coefficient of endogamy $f$ was estimated according to the method of moments (Weir, 1996). Genetic distance values were based on the coefficient of Shared Allele Distance (Bowcock et al., 1994). Principal component analysis was performed with NTSYSpc version 2.10z (Rohlf, 2005).

\section{Genetic Structure Analyses}

Analysis of molecular variance (AMOVA) was used to evaluate the partitioning of diversity within populations, between populations, and between groups of samples using Arlequin (Excoffier and Lischer, 2010). Groups were defined as African germplasm and Brazilian local population. Arlequin extends $F$ statistics to include groups as the highest hierarchical level. Groups are represented by the subscript $\mathrm{C}$, resulting in the following indexes: $\mathrm{F}_{\mathrm{ST}}$, for the variance among subpopulations $(\mathrm{S})$ relative to the total variance $(\mathrm{T}) ; \mathrm{F}_{\mathrm{SC}}$, for the variance among subpopulations (S) within groups $(\mathrm{C})$; and $\mathrm{F}_{\mathrm{CT}}$, for the variance among groups (C) relative to the total variance (T) (Excoffier et al., 1992). 
Table 2. Summary statistics for 15 microsatellite markers used for genotyping of 114 ruzigrass samples. Results for African germplasm accessions, Brazilian local population samples, and for the complete dataset are shown separately $(n=$ number of samples, $\mathrm{A}=$ number of alleles, $\mathrm{He}=$ expected heterozygosity, Ho = observed heterozygosity, PIC = polymorphism information content, $f=$ inbreeding coefficient).

\begin{tabular}{|c|c|c|c|c|c|c|c|c|c|c|c|c|c|c|c|c|c|c|}
\hline \multirow[b]{2}{*}{ Marker } & \multicolumn{6}{|c|}{ African germplasm } & \multicolumn{6}{|c|}{ Brazilian local population } & \multicolumn{6}{|c|}{ Complete dataset } \\
\hline & $n$ & A & $H_{\mathrm{E}}$ & $H_{\mathrm{O}}$ & PIC & $f$ & $n$ & A & $H_{\mathrm{E}}$ & $H_{\mathrm{O}}$ & $\mathrm{PIC}$ & $f$ & $n$ & A & $H_{\mathrm{E}}$ & $H_{\mathrm{O}}$ & $\mathrm{PIC}$ & $f$ \\
\hline Brz0075 & 62 & 13 & 0.866 & 0.710 & 0.862 & 0.196 & 49 & 20 & 0.920 & 0.837 & 0.926 & 0.111 & 111 & 20 & 0.915 & 0.766 & 0.914 & 0.172 \\
\hline Brz0017 & 62 & 13 & 0.891 & 0.903 & 0.889 & 0.002 & 42 & 17 & 0.886 & 0.810 & 0.889 & 0.110 & 104 & 18 & 0.910 & 0.865 & 0.909 & 0.059 \\
\hline Brz0116 & 63 & 16 & 0.903 & 0.921 & 0.903 & -0.004 & 49 & 18 & 0.904 & 0.956 & 0.907 & -0.035 & 108 & 23 & 0.921 & 0.935 & 0.921 & -0.006 \\
\hline Brz0047 & 60 & 13 & 0.852 & 0.883 & 0.844 & -0.020 & 45 & 22 & 0.889 & 0.796 & 0.891 & 0.125 & 109 & 21 & 0.895 & 0.844 & 0.891 & 0.066 \\
\hline Brz0087 & 63 & 17 & 0.906 & 0.810 & 0.908 & 0.123 & 51 & 23 & 0.898 & 0.765 & 0.902 & 0.168 & 114 & 27 & 0.935 & 0.789 & 0.937 & 0.165 \\
\hline Brz0130 & 63 & 14 & 0.892 & 0.714 & 0.892 & 0.214 & 51 & 19 & 0.912 & 0.784 & 0.917 & 0.159 & 114 & 20 & 0.923 & 0.746 & 0.923 & 0.200 \\
\hline Brz0131 & 63 & 6 & 0.621 & 0.476 & 0.596 & 0.249 & 51 & 8 & 0.690 & 0.451 & 0.655 & 0.364 & 114 & 9 & 0.664 & 0.465 & 0.632 & 0.308 \\
\hline Brz0147 & 63 & 18 & 0.900 & 0.889 & 0.900 & 0.028 & 46 & 13 & 0.928 & 0.863 & 0.935 & 0.090 & 114 & 30 & 0.932 & 0.877 & 0.934 & 0.068 \\
\hline Brz0031 & 62 & 9 & 0.839 & 0.661 & 0.829 & 0.227 & 51 & 28 & 0.852 & 0.630 & 0.850 & 0.280 & 108 & 14 & 0.870 & 0.648 & 0.862 & 0.264 \\
\hline Brz0004 & 61 & 15 & 0.901 & 0.754 & 0.903 & 0.179 & 48 & 28 & 0.891 & 0.646 & 0.897 & 0.295 & 109 & 31 & 0.923 & 0.706 & 0.924 & 0.244 \\
\hline Brz0156 & 53 & 12 & 0.819 & 0.811 & 0.806 & 0.028 & 51 & 14 & 0.836 & 0.843 & 0.826 & 0.011 & 104 & 16 & 0.842 & 0.827 & 0.829 & 0.028 \\
\hline Brz0180 & 40 & 10 & 0.830 & 0.775 & 0.822 & 0.091 & 51 & 15 & 0.776 & 0.578 & 0.768 & 0.277 & 85 & 16 & 0.889 & 0.745 & 0.886 & 0.205 \\
\hline Brz0089 & 47 & 14 & 0.869 & 0.766 & 0.869 & 0.140 & 45 & 14 & 0.818 & 0.725 & 0.811 & 0.132 & 98 & 19 & 0.832 & 0.671 & 0.821 & 0.172 \\
\hline Brz0038 & 61 & 6 & 0.744 & 0.787 & 0.714 & -0.041 & 51 & 6 & 0.678 & 0.627 & 0.632 & 0.095 & 112 & 7 & 0.725 & 0.714 & 0.688 & 0.024 \\
\hline Brz0015 & 63 & 9 & 0.802 & 0.825 & 0.784 & -0.013 & 50 & 14 & 0.857 & 0.860 & 0.851 & 0.017 & 113 & 15 & 0.853 & 0.841 & 0.841 & 0.023 \\
\hline Mean & - & 12.3 & 0.842 & 0.780 & 0.835 & 0.092 & - & 17.3 & 0.849 & 0.745 & 0.844 & 0.143 & - & 19.1 & 0.869 & 0.763 & 0.861 & 0.131 \\
\hline Total & 63 & 185 & - & - & - & - & 51 & 259 & - & - & - & - & 114 & 286 & - & - & - & - \\
\hline
\end{tabular}

Structure version 2.3.4 (Pritchard et al., 2000) was used to infer the population structure and ancestry of samples based on Bayesian statistics. At first all samples were analyzed with no prior assignment to populations or information about their sampling location. The parameter set for this analysis used the admixture model, and batch runs with correlated and independent allele frequencies among inferred populations were tested (burn-in 350,000; run-length 500,000). All other parameters were set to default values. A batch job with values of $K$ ranging from 1 to 11 was set up, with 20 independent runs for each $\mathrm{K}$.

Groups of samples of the African germplasm and Brazilian local population were then analyzed separately, with the same simulation parameters described above. For African germplasm samples, a batch job testing values of $\mathrm{K}$ ranging from 1 to 15 was carried, with 10 independent runs for each $\mathrm{K}$; for Brazilian local population samples, runs with $\mathrm{K}$ values ranging from one to six, with 10 independent runs for each $\mathrm{K}$ were performed.

The most probable value of $\mathrm{K}$ for each test was detected by $\Delta \mathrm{K}$ (Evanno et al., 2005), using Structure Harvester (Earl and vonHoldt, 2011). CLUMPP v.1.1.2 (Jakobsson and Rosenberg, 2007) was used to find the best alignments of replicate analyses from Structure, using the FullSearch Method, G' pairwise matrix similarity statistic, and weighing for the number of individuals in each population. Bar plots were generated with average results of runs for the most probable $\mathrm{K}$ value using distruct v.1.1 (Rosenberg, 2003). Samples were included in a cluster defined by Structure when a $Q$ value for any cluster was equal to or larger than 0.70 . Samples with $Q$ values smaller than 0.70 were defined as admixed.

Structure was also used with prior information regarding population origin to test for migrants in the African germplasm group of samples. This analysis shows the posterior probabilities that individuals are correctly assigned to their given populations, assuming that each accession is a population $(K=13)$. In addition, it shows the probabilities that individuals are in fact from other populations, or have ancestry in other populations. Parameters GENSBACK and MIGRPRIOR were set to 2 and 0.05 , respectively. These runs also had a burn-in of 350,000 iterations and a run-length of 500,000 repetitions.

\section{RESULTS \\ Descriptive Statistics}

Descriptive statistics were gathered for all markers and samples (Table 2) and for subsets of data, considering their sampling origin (African germplasm and Brazilian local population) (Table 3). Of the original 116 samples analyzed, two were excluded from the African germplasm group due to a high number of missing data.

The 63 samples belonging to 13 accessions of African germplasm included 185 alleles, with an average of 12.3 alleles per locus (Table 2). These values were lower than those found for the Brazilian local population. However, no significant differences in mean values of $\mathrm{He}, \mathrm{Ho}$, and PIC between the two groups of samples were found. The mean inbreeding coefficient $f$ for African germplasm accessions had a value of 0.092 , also lower than the value for the Brazilian local population $(f=0.143)$. Exact tests for Hardy Weinberg Equilibrium proportions $(\alpha<0.01)$ showed that eight and six out of the 15 SSR markers significantly deviated from expectations for African germplasm and Brazilian local population groups of samples, respectively.

\section{Population-specific Alleles}

To investigate whether there was a significant loss of alleles in the Brazilian local population when compared to 
Table 3. Analysis of molecular variance (AMOVA) and corresponding fixation indices between African and Brazilian samples, and among African germplasm accessions alone.

\begin{tabular}{lcccc}
\hline $\begin{array}{c}\text { Source of } \\
\text { variation }\end{array}$ & $\begin{array}{c}\text { Sum of } \\
\text { squares }\end{array}$ & $\begin{array}{c}\text { Variance } \\
\text { compo- } \\
\text { nents }\end{array}$ & $\begin{array}{c}\text { Percent- } \\
\text { age of } \\
\text { variation }\end{array}$ & $\begin{array}{c}\text { Fixation } \\
\text { index }\end{array}$ \\
\hline African accessions vs. & Brazilian accessions & & \\
$\quad \begin{array}{l}\text { Between groups } \\
\text { Among accessions }\end{array}$ & 29.4 & -0.14 & -2.34 & -0.02 \\
$\quad 144.70$ & 0.68 & 10.94 & 0.09 \\
$\quad$ within groups & & & & \\
Within accessions & 1166.84 & 5.69 & 91.40 & 0.11 \\
$\quad$ Total & 1341.00 & 6.23 & & \\
\hline African germplasm accessions & & & \\
Among accessions & 144.71 & 0.72 & 11.90 & 0.12 \\
$\quad$ Within accessions & 574.92 & 5.34 & 88.10 & \\
Total & 719.63 & 6.05 & & \\
\hline
\end{tabular}

African germplasm, we looked for exclusive alleles in the different groups of ruzigrass samples. There were more alleles that were exclusive to the population collected in Brazil (120 in total) than to all of the African germplasm accessions (19 exclusive alleles) considered together. Approximately $87 \%$ of the alleles that were only found in the population collected in Brazil were rare (with a frequency $<0.05$ ), while the remaining $13 \%$ were of intermediate frequency $(0.05<$ frequency $<0.30)$. In the African accessions, $\sim 68 \%$ of the exclusive alleles were rare, and $32 \%$ were of intermediate frequency.

\section{Analysis of Molecular Variance}

For the purpose of analysis, samples were first divided into two major groups, namely those from African germplasm accessions and those collected in Brazil. When grouped under such categories, no significant structure was detected (slightly negative values both for the variance component of variation among groups and its corresponding fixation index $\mathrm{F}_{\mathrm{CT}}$ were found) (Table 3). Variation among accessions within groups accounted for $10.94 \%$ of the total variation $\left(\mathrm{F}_{\mathrm{ST}}=0.09\right.$, significant at $\left.\alpha<0.01, p=0.0000\right)$, while variation within accessions explained $91.4 \%$ of the total variation $\left(\mathrm{F}_{\mathrm{SC}}=0.11\right.$, significant at $\left.\alpha<0.01, p=0.0000\right)$.

Genetic structure analyses including only the African accessions showed an average $\mathrm{F}_{\mathrm{ST}}$ value of 0.12 over all loci (significant at $\alpha<0.01, p=0.0000$ ) (Table 3). Partitioning of the variation verified by AMOVA showed that $11.9 \%$ of the variation was caused by differences among accessions. Differences within accessions accounted for $88.1 \%$ of the variation.

\section{Genetic Structure of Ruzigrass Populations}

Initial tests using the Structure program showed that analyses using independent allele frequencies among inferred populations yielded more consistent results for the definition of the most probable value of $K$. When the entire set of 114 samples was subjected to population structure analysis, $\Delta \mathrm{K}$ for these runs detected a peak at $K=3$ (Fig. 1a). The $Q$ values assigning samples to the three clusters were depicted in red, green, and blue (Fig. 1b). The first 51 columns in Fig. 1b correspond to the Brazilian local population, and the remaining 63 to African germplasm accessions. Cluster 1 in Fig. 1b, with $Q$ values represented in red, included 34 African germplasm samples (of a total of 63), and one sample from the Brazilian local population (sample no. 9). Cluster 2 in Fig. 1b, shown in green, included 22 African germplasm samples. Therefore, most of the African germplasm accessions showed greater proportions of ancestry for Clusters 1 and $2(88.9 \%$, or 56 out of 63 samples, with the remaining seven samples from this group being admixed-each of them identified with an asterisk on Fig. 1b). Cluster 3, shown in blue in Fig. 1b, included 47 out of 51 samples of the Brazilian local population. Three samples collected in Brazil showed admixed ancestry (sample no. 14, 15, and 48-also identified with asterisks), while one, as already mentioned (sample no. 9), showed a higher Q value for Cluster 1. Net nucleotide distance values (Falush et al., 2003) in pairwise comparisons between clusters presented average values of 0.05 between Clusters 1 and 2, 0.04 between Clusters 1 and 3, and 0.04 between Clusters 2 and 3. This can be interpreted as the average probability that a pair of alleles from two clusters is different, less their respective within-population heterozygosities (Pritchard et al., 2010).

When only the African ruzigrass samples were subjected to population structure analysis, $\Delta \mathrm{K}$ showed a higher peak for $K=2$ (Fig. 1a). The $\mathrm{Q}$ values assigning African germplasm samples to the two clusters were depicted again in red and green (Fig. 1c). Cluster 1 (in red) included 23 samples, Cluster 2 included 33 samples (in green), and the remaining seven samples were admixed (Fig. 1c-identified with asterisks). Four accessions included only samples whose ancestry was inferred as being from a single Cluster: accessions BRA-005541 (samples 1-5) and BRA-005665 (samples 54-58), with all individuals belonging to Cluster 1; BRA-005592 (samples 25-30), and BRA-005614 (3539), with all individuals belonging to Cluster 2 .

We then checked whether samples from the African germplasm group would be correctly assigned to their respective accessions, using prior information regarding population origin, under the assumption that each accession represents a distinct population. Out of 63 individual plants, 47 would more probably belong to their assumed population (i.e., the analysis showed high probabilities that they would belong to the accession they were initially assigned to). Sixteen samples, however, showed higher probabilities of being from another accession. The African germplasm accessions to which each sample most probably belongs and the respective probability values are presented on Table 4 .

Finally, runs that included only the Brazilian local population showed no signs of structure for this group of samples (data not shown). 

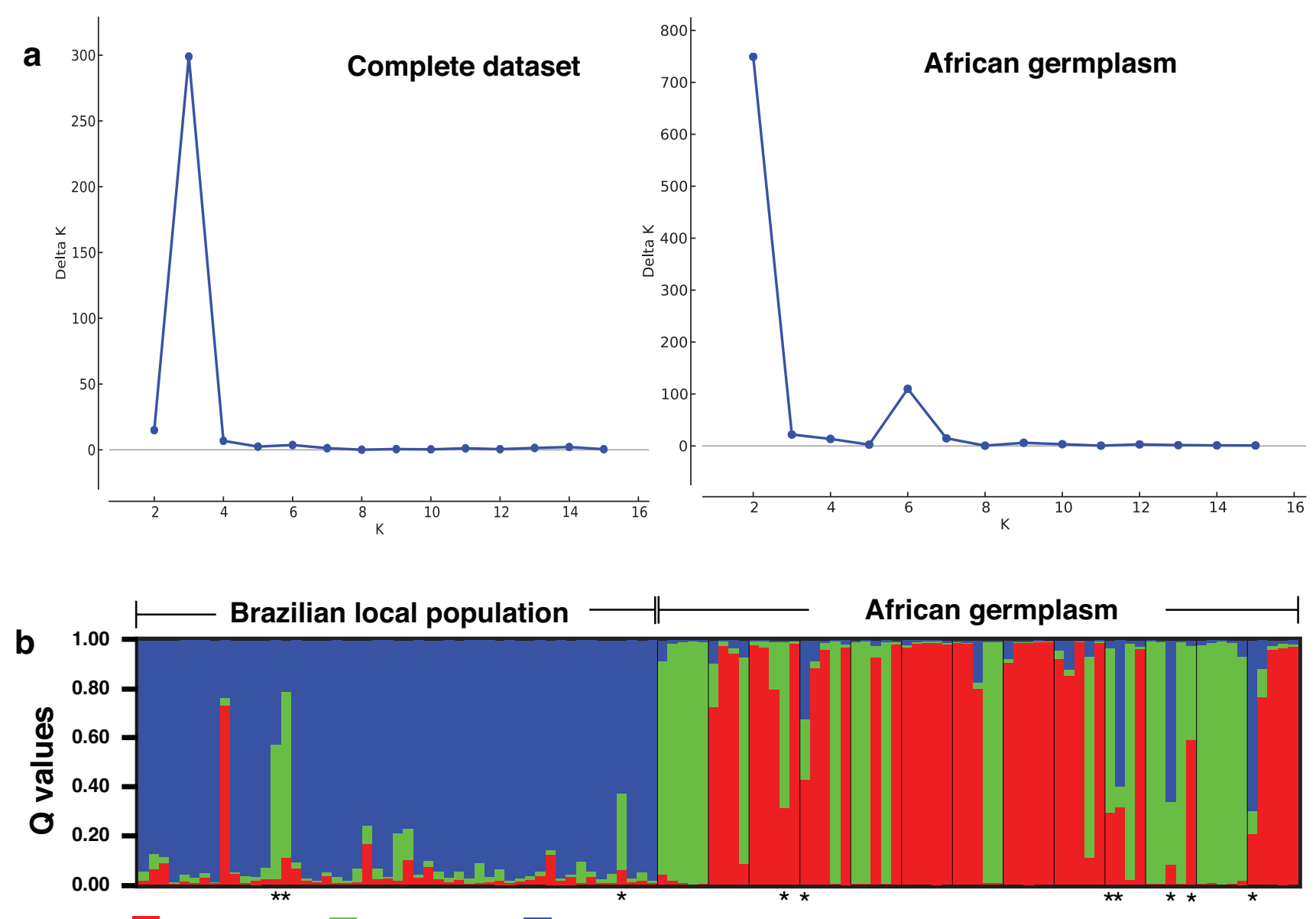

Cluster $1 \quad$ Cluster 2 Cluster 3



Figure 1. (a) Estimates of K for all 114 ruzigrass samples considered in the study (left) and for the African germplasm accessions (right); (b) Proportion of ancestry of ruzigrass samples based on Structure analysis for $\mathrm{K}=3$ (African germplasm accessions and Brazilian local populations) and (c) $K=2$ (only African germplasm accessions). Samples were allocated to clusters based on $Q$ values ( $Q>0.70$ ). Admixed samples identified with an asterisk.

\section{Clustering Analyses}

We used the same colors of the ancestry groups inferred by Structure in Fig. 1b and 1c to identify samples in a principal component analysis (PCA) plot (Fig. 2). The PCA plot shows that the samples from African germplasm accessions (red and green dots) were spread out over the PCA plane (Fig. 2), with some overlapping with accessions from the Brazilian local population (blue dots). While the former composed two groups, the latter appeared to be more constrained to the upper right quadrant of the PCA plane. The Brazilian local population was also mainly composed of one ancestry group (Fig. 2), as previously inferred by Structure, with four exceptions: samples 14, 15, and 48 were admixed (black dots), and sample 9 most probably belonged to Group 1. Seven admixed samples from African germplasm accessions are also shown in black (Fig. 2). 
Table 4. List of ruzigrass samples of African germplasm which more probably belong to a different accession. Codes in parenthesis show the accession that would most likely include these samples.

\begin{tabular}{ccc}
\hline Sample & $\begin{array}{c}\text { Probability of being } \\
\text { from assumed } \\
\text { accession }\end{array}$ & $\begin{array}{c}\text { Probability of being } \\
\text { from other } \\
\text { accession }\end{array}$ \\
\hline AG-02 sample 3 & 0.006 & 0.984 (AG-03) \\
AG-04 sample 1 & 0.267 & 0.287 (AG-10) \\
AG-04 sample 3 & 0.008 & 0.914 (AG-03) \\
AG-04 sample 4 & 0 & 0.651 (AG-01) \\
AG-05 sample 1 & 0 & 1.000 (AG-12) \\
AG-05 sample 2 & 0.001 & 0.902 (AG-01) \\
AG-05 sample 3 & 0.048 & 0.886 (AG-04) \\
AG-05 sample 4 & 0 & 1.000 (AG-12) \\
AG-05 sample 5 & 0.136 & 0.598 (AG-03) \\
AG-07 sample 1 & 0.016 & 0.958 (AG-08) \\
AG-07 sample 2 & 0.039 & 0.878 (AG-08) \\
AG-07 sample 4 & 0.003 & 0.996 (AG-01) \\
AG-07 sample 5 & 0.001 & 0.996 (AG-01) \\
AG-09 sample 4 & 0 & 0.239 (AG-03) \\
AG-11 sample 5 & 0.058 & 0.632 (AG-03) \\
AG-12 sample 3 & 0.076 & 0.510 (AG-01) \\
\hline
\end{tabular}

\section{DISCUSSION}

Ruzigrass is the only diploid species with sexual reproduction among those in the Brachiaria genus currently used as tropical forages. The fact that it presents sexual reproduction makes it particularly interesting from a breeder's perspective, since methods based on recombination and selection can be applied on breeding programs. The fact that it is diploid makes the investigation of its genome a task that is easier to attain than in other polyploid Brachiaria forages, such as B. brizantha, B. decumbens, and B. humidicola, which have much larger and certainly more complex genomes.

This is the first report of the use of microsatellite markers on the analysis of genetic diversity and structure of ruzigrass germplasm. It provides a first look at how diverse a sample of the African populations collected in the mid-1980s are. It is also the first time a population of the ruzigrass open-pollinated variety commercially available in Brazil was analyzed with this type of molecular marker. It brings a perspective on how the genetic diversity of the crop was affected after its introduction in Brazil, and after countless recombination events took place in seed production fields.

Comparisons of levels of genetic diversity in ruzigrass presented here with those from previous studies are not reasonable at this moment. Published studies in ruzigrass were based on dominant markers such as RAPDs (Ambiel et al., 2008, 2010) and ISSRs (Azevedo et al., 2011). Ambiel et al. $(2008,2010)$ used RAPDs to assess dissimilarity between 44 germplasm accessions and cultivars of different Brachiaria species, not focusing on one species in particular. Azevedo et al. (2011) used ISSR markers to genotype a set of 93 samples of the ruzigrass breeding program carried by Embrapa, also assessing genetic distance between these samples and those from other Brachiaria species. Even though these studies did present results from AMOVA, they primarily focused on how diversity was partitioned within and between species (Ambiel et al., 2008, 2010; Azevedo et al., 2011).

Other Brachiaria species used as tropical forages also had samples of their germplasm collections characterized with microsatellite markers, with available studies for $B$. brizantha (Vigna et al., 2011b) and B. humidicola (Jungmann et al., 2010). However, due to the polyploid nature of these species, authors interpreted SSRs as dominant markers, based on the presence or absence of alleles (Jungmann et al., 2010; Vigna et al., 2011b). Notwithstanding, they performed diversity and structure analyses of these germplasm collections. Due to this different interpretation of molecular markers, and to the fact that they dealt with different species, with a different reproductive mode (mostly apomicts with one or two sexual accessions), we believe that comparing their results with those presented here would not be reasonable.

The multiplex panels of SSR markers used in this study are a subset of the panels that had been proposed as a result of an effort for the development of SSR markers for ruzigrass using a draft genome assembly generated by next-generation sequencing of single-end reads (Silva et al., 2013). This was the first time these markers were tested on a large number of samples, being successfully used for the characterization of ruzigrass germplasm accessions and its commercially available cultivar. Marker amplification and interpretation was reproduced in a different laboratory, by a different team, and allowed the use of all of the markers included in the subset.

The predominantly outcrossing nature of ruzigrass was evident in the low values of the inbreeding coefficient $(f)$, and high values of $H_{\mathrm{E}}$ and $H_{\mathrm{O}}$ for all groups of samples. However, values of $f$ indicate that a low level of self-pollination, or crossing between closely related plants, might occur ( $f$ was 0.092 for African germplasm accessions, and 0.143 for the Brazilian local population). The frequency of null alleles in this experiment was not estimated, and their occurrence could also be one of the causes for the observed excess of homozygotes in these ruzigrass samples (DeWoody et al., 2006). Outcrossing rates for ruzigrass have never been properly measured, and we are currently addressing this question with SSR markers.

The Brazilian local population presented more alleles per locus, but similar values of $H_{\mathrm{O}}$ and $\mathrm{He}$ when compared to African accessions. It also presented more exclusive alleles than the African accessions considered as a group. The fact that more exclusive alleles were found in the samples collected in Brazil was surprising since the African accessions were collected in natural fields of three different countries (Burundi, Kenya, and Rwanda) included in the center of diversity of the species. However, 


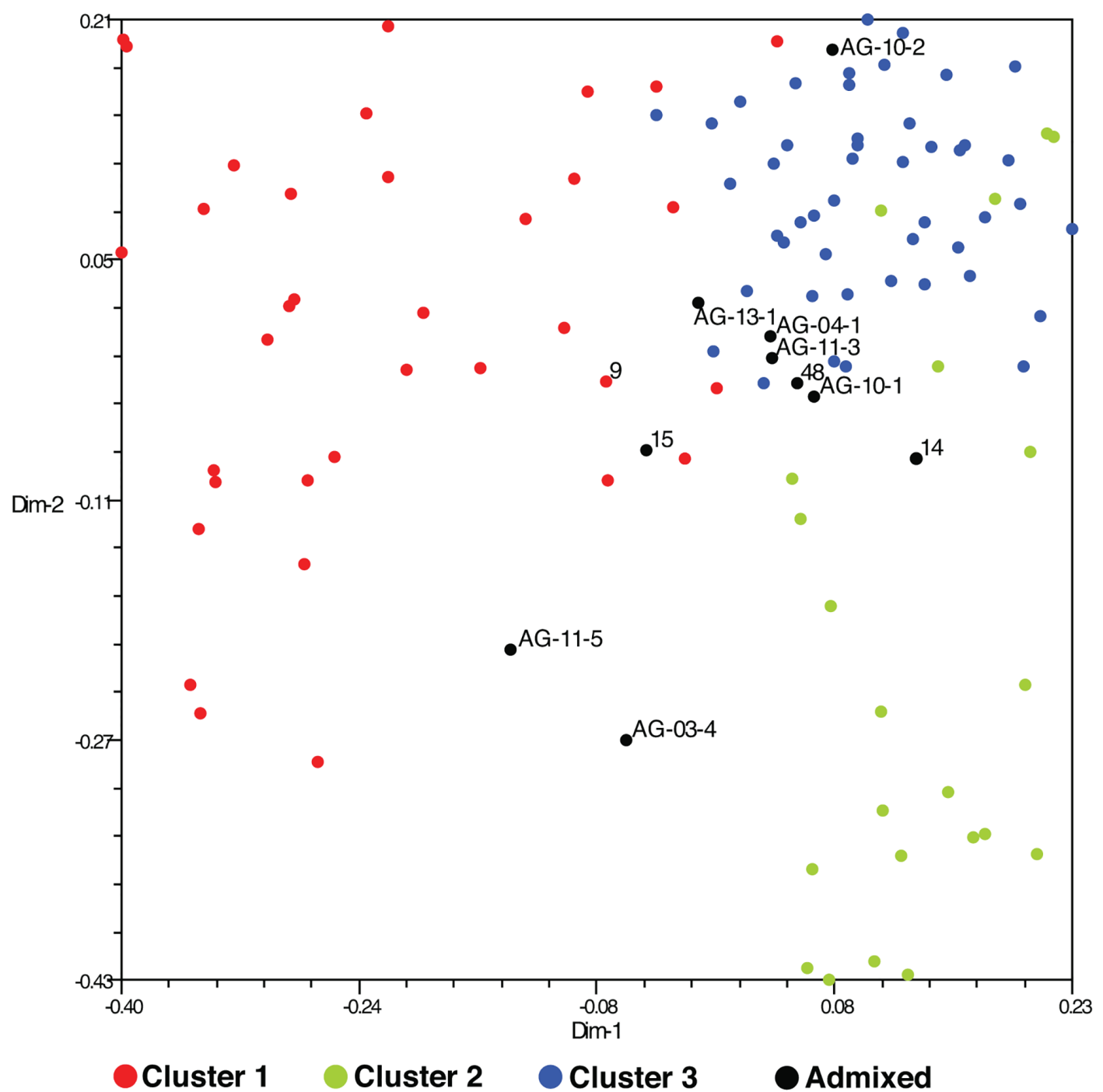

Figure 2. Principal component analysis plot based on Shared-Allele Distances of ruzigrass samples. Colors of the dots refer to Clusters 1 (red), 2 (green), and 3 (blue), defined based on Q values estimated for each ruzigrass sample. Dots colored in black had admixed ancestry as inferred by Structure. $A G=$ African germplasm.

considering that only a few plants from each germplasm accession were genotyped, it is possible that the sample of African accessions studied here do present some of these alleles, but they have gone undetected due to small sample sizes. There is also the possibility that some of these exclusive alleles are due to multiple introductions of ruzigrass in Brazil from different locations in Africa followed by intercross. Another possibility is that the original African population from which this open pollinated population originated was genetically distinct (and more diverse) than the samples of African Germoplasm analyzed here. Unfortunately, the accession corresponding to the Kennedy cultivar (BRA-000281, CIAT 605, originally collected in Rwanda) was not available for this study so that some of these possibilities could be properly addressed. Genotyping a sample from this accession kept at long-term storage conditions would provide a good reference for comparisons with the commercial open-pollinated variety being currently produced in Brazil.
Clustering analysis using PCA allowed for the observation of distinct clusters, and a clear separation between African and Brazilian accessions, with a few exceptions. Different types of analyses on the genetic structure of these groups of samples showed that although population structure was detected by the Bayesian approach implemented in the software Structure, it was not significant between African accessions and Brazilian samples (as seen by the slightly negative values of $\mathrm{F}_{\mathrm{CT}}$ between groups in Table 3). This was corroborated by the net nucleotide distance value estimated (0.05 between the three inferred clusters). Finally, AMOVA showed that $10.94 \%$ of the total variation was caused by differences among accessions within groups, and $91.4 \%$ explained by differences within accessions. Such partition of genetic diversity is expected from a typically outcrossing species (Loveless and Hamrick, 1984; Hamrick and Godt, 1996; Booy et al., 2000).

When only African accessions were analyzed, $\mathrm{F}_{\mathrm{ST}}$ values indicated a moderate level of genetic structure $\left(\mathrm{F}_{\mathrm{ST}}\right.$ 
$=0.12$. This was confirmed by AMOVA, with $11.90 \%$ of the variation caused by differences among accessions. Structure population analysis, on the other hand, detected only two main clusters subdividing the African accessions, and seven admixed samples. Out of 63 samples of African accessions, 16 would more probably belong to different populations. If one assumes that these samples are still representative of the original genetic structure of African ruzigrass populations, this could be caused by gene flow between original populations, before they were collected. However, contamination during seed regeneration, with crosses between accessions and genetic recombination taking place in the field before depositing the accessions in the long-term Base Collection, is also a possibility.

Altogether, our data indicates that the introduction of ruzigrass populations in Brazil, tracing back to the cultivar Kennedy from Australia (Keller-Grein et al., 1996), did not necessarily cause a significant loss of alleles or decreases in genetic diversity as compared to a sample of the original African accessions kept for the last $30 \mathrm{yr}$ in the long-term Base Collection. These accessions seem as diverse as samples of local populations collected in ruzigrass-producing regions of Brazil, such as Minas Gerais. Although not as widespread as B. brizantha, which covers approximately 70 million hectares of pasture in Brazil, ruzigrass also covers some million hectares in tropical regions. Ruzigrass was introduced in Brazil by farmers decades ago, recombining and being naturally selected in the field for years, in pastures that have either been abandoned or are not yet renewed. It is likely that some of these small populations include individuals especially adapted to environmental conditions and stresses to which they have been submitted in Brazil for all these years. These populations offer great opportunities for germplasm collection to increase the number of conserved ruzigrass accessions kept in gene banks, while also bringing higher chances of harboring favorable alleles that will be useful for ongoing and future breeding strategies in the species. Conservation efforts, therefore, should capitalize on local collection of ruzigrass populations, before attempts to access germplasm in its center of diversity are undertaken.

\section{CONCLUSIONS}

Similar levels of genetic diversity were observed between ruzigrass samples collected in Africa and in Brazil. In addition, the absence of genetic structure between these two groups of samples indicate that conservation efforts focused on the enrichment of germplasm collections of ruzigrass can be directed at local populations of this species, established in Brazil several decades ago. Recombination and selection for environmental conditions taking place at these local populations may have contributed to the occurrence of traits that will be useful for breeding programs for this species. These breeding programs will benefit from a broader genetic base and from the introgression of useful phenotypic traits both at a diploid level (for instance, in the recurrent selection programs), and for the generation of inter-specific hybrids after chromosome doubling.

\section{Acknowledgments}

We thank Dr. Juliano Gomes Pádua for providing ruzigrass germplasm from the Base Collection at Embrapa Genetic Resources and Biotechnology. We thank Cooperativa Agropecuária Pioneira (COOAPI) at Chapada Gaúcha (MG) for their help in the collection of the local ruzigrass population. This work was sponsored by Embrapa Macroprograma 2 (02.12.02.002.00.00), and partially funded by the Fundação de Amparo a Pesquisa de Minas Gerais (FAPEMIG).

\section{References}

Ambiel, A.C., L.M. Guaberto, T.M. Vanderlei, and N.B. Machado Neto. 2008. RAPD grouping of accesses and cultivars of three Brachiaria species. (In Portuguese, with English abstract.) Acta Sci.-. Agron. 30:457-464.

Ambiel, A.C., N.B. Machado Neto, L.M. Guaberto, and T.M. Vanderlei. 2010. Brachiaria germplasm dissimilarity as shown by RAPD markers. Crop Breed. Appl. Biotechnol. 10:55-64. doi:10.12702/19847033.v10n01a08

Azevedo, A.L.S., P.P. Costa, M.A. Machado, C.P.M. de Paula, and F.S. Sobrinho. 2011. High degree of genetic diversity among genotypes of the forage grass Brachiaria ruziziensis (Poaceae) detected with ISSR markers. Genet. Mol. Res. 10:3530-3538. doi:10.4238/2011. November.17.5

Azevedo, A.L.S., P.P. Costa, J.C. Machado, M.A. Machado, A. Vander Pereira, and F.J. da Silva Ledo. 2012. Cross species amplification of Pennisetum glaucum microsatellite markers in Pennisetum purpureum and genetic diversity of napier grass accessions. Crop Sci. 52:1776-1785. doi:10.2135/cropsci2011.09.0480

Booy, G., R.J.J. Hendriks, M.J.M. Smulders, J.M. van Groenendael, and B. Vosman. 2000. Genetic diversity and the survival of populations. Plant Biol. 2:379-395. doi:10.1055/s-2000-5958

Borges, V., F.S. Sobrinho, F.J.S. Lédo, and M.M. Kopp. 2011. Association between traits and path analysis in half-sib progeny selection of Brachiaria ruziziensis. (In Portuguese, with English abstract.) Rev. Ceres 58:765-772. doi:10.1590/S0034-737X2011000600013

Bowcock, A., A. Ruiz-Linhares, J. Tomfohrde, E. Minch, J. Kidd, and L. Cavalli-Sforza. 1994. High resolution of human evolutionary trees with polymorphic microsatellites. Nature (London) 368:455-457. doi:10.1038/368455a0

Brazauskas, G., I. Lenk, M.G. Pedersen, B. Studer, and T. Lübberstedt. 2011. Genetic variation, population structure, and linkage disequilibrium in European elite germplasm of perennial ryegrass. Plant Sci. 181:412-420. doi:10.1016/j.plantsci.2011.06.013

Bushman, B.S., S.E. Warnke, K.L. Amundsen, K.M. Combs, and P.G. Johnson. 2013. Molecular markers highlight variation within and among Kentucky bluegrass varieties and accessions. Crop Sci. 53:2245-2254.

Cidade, F.W., B.B. Vigna, F.H. de Souza, J.F.M. Valls, M. Dall'Agnol, M.I. Zucchi et al. 2013. Genetic variation in polyploid forage grass: Assessing the molecular genetic variability in the Paspalum genus. BMC Genet. 14:50. doi:10.1186/1471-2156-14-50 
de Sousa, A.C.B., L. Jank, T. de Campos, D.A. Sforça, M.I. Zucchi, and A.P. de Souza. 2011. Molecular diversity and genetic structure of Guineagrass (Panicum maximum Jacq.), a tropical pPasture grass. Trop. Plant Biol. 4:185-202. doi:10.1007/s12042-011-9081-6

DeWoody, J., J.D. Nason, and V.D. Hipkins. 2006. Mitigating scoring errors in microsatellite data from wild populations. Mol. Ecol. Notes 6:951-957. doi:10.1111/j.1471-8286.2006.01449.x

Doyle, J.J., and J.L. Doyle. 1987. A rapid DNA isolation procedure for small quantities of fresh leaf tissue. Phytochem. Bull. 19:11-15.

Earl, D.A., and B.M. vonHoldt. 2011. STRUCTURE HARVESTER: A website and program for visualizing STRUCTURE output and implementing the Evanno method. Conserv. Genet. Resour. 4:359361. doi:10.1007/s12686-011-9548-7

Evanno, G., S. Regnaut, and J. Goudet. 2005. Detecting the number of clusters of individuals using the software STRUCTURE: A simulation study. Mol. Ecol. 14:2611-2620. doi:10.1111/j.1365294X.2005.02553.x

Excoffier, L., and H.E.L. Lischer. 2010. Arlequin suite ver 3.5: A new series of programs to perform population genetics analyses under Linux and Windows. Mol. Ecol. Resour. 10:564-567. doi:10.1111/ j.1755-0998.2010.02847.x

Excoffier, L., P.E. Smouse, and J.M. Quattro. 1992. Analysis of molecular variance inferred from metric distances among DNA haplotypes: Application to human mitochondrial DNA restriction data. Genetics 131:479-491.

Falush, D., T. Wirth, B. Linz, J.K. Pritchard, M. Stephens, M. Kidd et al. 2003. Traces of human migrations in Helicobacter pylori populations. Science (Washington, DC) 299:1582-1585. doi:10.1126/science. 1080857

Ferreira, M., and D. Grattapaglia. 1998. Introduction to the use of molecular markers in genetic analysis. Documentos, 20. (In Portuguese.) Embrapa Cenargen, Brasilia, DF, Brasilia.

Hamrick, J.L., and M.J.W. Godt. 1996. Effects of life history traits on genetic diversity in plant species. Phil. Trans. R Soc. B 351:1291-1298.

Hand, M.L., N.O.I. Cogan, and J.W. Forster. 2012. Molecular characterisation and interpretation of genetic diversity within globally distributed germplasm collections of tall fescue (Festuca arundinacea Schreb.) and meadow fescue (F. pratensis Huds.). Theor. Appl. Genet. 124:1127-1137. doi:10.1007/s00122-011-1774-6

Honig, J.A., V. Averello, S.A. Bonos, and W.A. Meyer. 2012. Classification of Kentucky bluegrass (Poa pratensis L.) cultivars and accessions based on microsatellite (simple sequence repeat) markers. HortScience 47:1356-1366.

Idury, R.M., and L.R. Cardon. 1997. A simple method for automated allele binning in microsatellite markers. Genome Res. 7:1104-1109.

Jakobsson, M., and N.A. Rosenberg. 2007. CLUMPP: A cluster matching and permutation program for dealing with label switching and multimodality in analysis of population structure. Bioinformatics 23:1801-1806. doi:10.1093/bioinformatics/btm233

Jewell, M.C., Y. Zhou, D.S. Loch, I.D. Godwin, and C.J. Lambrides. 2012. Maximizing genetic, morphological, and geographic diversity in a core collection of Australian bermudagrass. Crop Sci. 52:879889. doi:10.2135/cropsci2011.09.0497

Jungmann, L., A.C.B. Sousa, J. Paiva, P.M. Francisco, B.B.Z. Vigna, C.B. do Valle et al. 2009a. Isolation and characterization of microsatellite markers for Brachiaria brizantha (Hochst. ex A. Rich.). Stap. Conserv. Genet. 10:1873-1876. doi:10.1007/s10592-009-9839-7

Jungmann, L., B.B.Z. Vigna, K.R. Boldrini, A.C.B. Sousa, C.B. do Valle, R.M.S. Resende et al. 2010. Genetic diversity and population structure analysis of the tropical pasture grass Brachiaria humidicola based on microsatellites, cytogenetics, morphological traits, and geographical origin. Genome 53:698-709. doi:10.1139/G10-055
Jungmann, L., B.B.Z. Vigna, J. Paiva, A.C.B. Sousa, C.B. do Valle, P.R. Laborda et al. 2009b. Development of microsatellite markers for Brachiaria humidicola (Rendle). Schweick. Conserv. Genet. Resour. 1:475-479. doi:10.1007/s12686-009-9111-y

Keller-Grein, G., B.L. Maass, and J. Hanson. 1996. Natural variation in Brachiaria and existing germplasm collections. In: J.W. Miles, B.L. Maass, and C.B. do Valle, editors, Brachiaria: Biology, agronomy and improvement. CIAT, Colombia. p. 16-42.

Kichel, A.N., D.J. Bungenstab, A.H. Zimmer, C.O. Soares, and R.G. Almeida. 2014. Crop-livestock-forestry integration and the progress of the Brazilian agriculture. In: D.J. Bungenstab and R.G. Almeida, editors, Integrated crop-livestock-forestry systems, a Brazilian experience for sustainable farming. Embrapa, Brasilia, DF, Brazil. p. 19-26.

Kubik, C., M. Sawkins, W.A. Meyer, and B.S. Gaut. 2001. Genetic diversity in seven perennial ryegrass (Lolium perenne L.) cultivars based on SSR markers. Crop Sci. 41:1565-1572. doi:10.2135/ cropsci2001.4151565x

Liu, K., and S.V. Muse. 2005. PowerMarker: An integrated analysis environment for genetic marker analysis. Bioinformatics 21:21282129. doi:10.1093/bioinformatics/bti282

Loveless, M.D., and J.L. Hamrick. 1984. Ecological determinants of genetic structure in plant populations. Annu. Rev. Ecol. Syst. 15:6595. doi:10.1146/annurev.es.15.110184.000433

Nei, M. 1987. Molecular evolutionary genetics. Columbia Univ. Press, New York.

Pritchard, J.K., M. Stephens, and P. Donnelly. 2000. Inference of population structure using multilocus genotype data. Genetics 155:945-959.

Pritchard, J.K., X. Wen, and D. Falush. 2010. Documentation for structure software: Version 2.3. Stanford Univ. http://pritchardlab.stanford.edu/structure_software/release_versions/v2.3.4/structure_doc. pdf (accessed 2 Sept. 2015).

Rohlf, F. 2005. NTSYSpc numerical taxonomy and multivariate analysis system version 2.10. Exerter Publ., Setauket, NY.

Rosenberg, N.A. 2003. distruct: A program for the graphical display of population structure. Mol. Ecol. Notes 4:137-138. doi:10.1046/ j.1471-8286.2003.00566.x

Silva, P.I., A.M. Martins, E.G. Gouvea, M. Pessoa-Filho, and M.E. Ferreira. 2013. Development and validation of microsatellite markers for Brachiaria ruziziensis obtained by partial genome assembly of Illumina single-end reads. BMC Genomics 14:17. doi:10.1186/1471-2164-14-17

Souza Sobrinho, F., H. Carneiro, F.J.S. Ledo, and F.F. de Souza. 2009a. Forage yield and quality of Brachiaria in the northern Fluminense region. (In Portuguese.) Pesquisa Aplicada \& Agrotecnologia 2:7-12.

Souza Sobrinho, F., F.J.S. Ledo, M.M. Kopp, A.V. Pereira, and F.F. Souza. 2009b. Breeding of forage grasses at Embrapa Dairy Cattle. In: A.R. Evangelista and F.F. Souza, editors, Simpósio e Congresso de Forragicultura e Pastagens. (In Portuguese.) Univ. Federal de Lavras, Lavras, MG, Brazil. p. 98-111.

Vigna, B.B., G.C. Alleoni, L. Jungmann, C.B. do Valle, and A.P. de Souza. 2011a. New microsatellite markers developed from Urochloa humidicola (Poaceae) and cross amplification in different Urochloa species. BMC Res. Notes 4:523. doi:10.1186/1756-0500-4-523

Vigna, B.B.Z., L. Jungmann, P.M. Francisco, M.I. Zucchi, C.B. do Valle, and A.P. Souza. 2011b. Genetic diversity and population structure of the Brachiaria brizantha Germplasm. Tropical Plant Biol. 4:157-169. doi:10.1007/s12042-011-9078-1

Weir, B.S. 1996. Genetic Data Analysis II. Sinauer Associates, Sunderland, MA. 